\title{
Analyzing the Factors Affecting Purchase Intention of Drugstore Beauty Products
}

\author{
Regita Cahya Maharani ${ }^{a}$, Christian Haposan Pangaribuan ${ }^{b}$ \\ a, b Sampoerna University, Jakarta, Indonesia \\ ${ }^{a}$ regita.maharani@my.sampoernauniversity.ac.id \\ ${ }^{\mathrm{b}}$ christian.pangaribuan@sampoernauniversity.ac.id
}

\begin{abstract}
Objective - The objective of this study is to identify the key elements of buying beauty products in drugstore chains, discuss the reasons and factors behind why these drugstore chains had become the customers' preference to visit and purchase beauty products, and to find out the relation of store convenience of drugstore chains to purchase intention of their beauty products.

Methodology - The method used in this research is quantitative using an online survey started in November 2020. From 132 distributed questionnaires using Google Form link, only 106 responses are valid.

Findings - The results reveal that shopping enjoyment and competitive price to have a significant influence on intention to purchase. However, the relationship between convenience and purchase intention was not supported.

Novelty - Previous studies have predominantly examined the main effect of shopping convenience on purchase intention. This study extends our understanding of this relationship by highlighting the non-significant result in the convenience-intention linkage.

Keywords: Purchase Intention; Beauty Products; Enjoyment; Convenience; Price
\end{abstract}

JEL Classification: E30, L66, L81

Article info: Received 1 March 2021; Revised 5 April 2021; Accepted 3 May 2021

Article Correspondence: christian.pangaribuan@sampoernauniversity.ac.id

Recommended Citation: Maharani, R. C. \& Pangaribuan, C. H. (2021). Analyzing the Factors Affecting Purchase Intention of Drugstore Beauty Products. Journal of Multidisciplinary Issues, 1(1), 1-7.

\section{INTRODUCTION}

Beauty products can trace their history as early as to the ancient Egyptian civilization. Since the earliest periods of Egyptian history, cosmetics have been commonly used for aesthetic purposes and their medical, magical, or religious attributes. Not only were men and women adorned with cosmetics, but their mummies, statues, and statues of their gods and goddesses were also adorned (El-Kilany et al., 2017). The beauty products and skincare habits we know today are surprisingly similar to those of ancient Egyptians. Oils and creams were used for protection against the hot Egyptian sun and dry winds. Myrrh, thyme, marjoram, chamomile, lavender, lily, peppermint, rosemary, cedar, rose, aloe, olive oil, sesame oil, and almond oil provided the essential ingredients of most perfumes that were used in religious ritual and embalming the dead. For the lips, cheeks, and nails, a clay called 'red ochre' was ground and mixed with water. Henna was used to dye fingernails yellow or orange. Makeup was stored in unique jars that were kept in special makeup boxes. Women would carry their makeup boxes to parties and keep them under their chairs (Chaudhri et al., 2009).

Beauty products developed with the advancement of technology and the ever-changing beauty standards, but the bottom line is always the same; to enhance beauty. Skincare products, specifically, are used to clean, soothe, restore, reinforce, protect, and treat our skin and hence to keep it in "good condition" (Surber et al., 2016). 
Beauty products are now ubiquitous and displayed on the shelves of drugstore chains, e.g., Watsons and Guardian. People associate drugstore with medicine, prescriptions, and health care products. However, with various beauty products being sold, people also frequent these drugstores to search for their favorite Korean sheet mask, a new foundation shade they need for a party, or simply as moisturizing lotion. Thus, this paper will analyze the factors affecting the purchase intention of beauty products sold in drugstore chains.

This research outcome will provide a better understanding of how customers in Indonesia view drugstores as a place where they can come for a cure to fever and cough and a go-to place where they can find their favorite beauty products. The result can also be used as a guide for drugstore chains to improve their marketing strategy to fit the market preference.

Drugstore beauty products, the opposite of high-end beauty products, is a cheaper option of beauty brands usually sold at drugstores. In contrast, high-end beauty products come at a higher price point and are usually sold at specialty stores. Drugstore beauty products are favorite to those who want quality at an affordable price tag. The drugstore chains where these products are being sold play a crucial role in introducing and selling these products to customers.

With such an important role, drugstore chains need deeper insight on what, how, and who their market is and develop the right marketing strategy to improve their service. Its small range of respondents limits this research; teenagers and young adults with an age range of 14-25 because from age 14 and beyond, skincare is necessary with hormonal change and diet to start affecting the skin condition.

In this paper, the researchers use quantitative analysis as a tool by evaluating factors that affect individuals to visit and purchase beauty products from drugstore chains. The objectives are to identify the key elements of buying beauty products in drugstore chains, discuss the reasons and factors behind why these drugstore chains had become the customers' preference to visit and purchase beauty products, and to find out the relation of store convenience of drugstore chains to purchase intention of their beauty products.

The paper is aimed to answer the following questions: (1) Why customers favor and frequent drugstore chains to purchase beauty products? (2) What are the right marketing strategies to apply to drugstore chains to enhance their beauty products sales?

\section{LITERATURE REVIEW}

The Theory of Planned Behavior (e.g., Ajzen, 1991) is an established, social-psychological model of human behavior with a relatively parsimonious structure based on five key factors: attitudes, subjective norms, perceived behavior control, intentions, and behavior. Attitude, subjective norms, and perceived behavior control are assumed to influence behavioral intentions, which, in turn, are assumed to affect behavior more directly (Passafaro et al., 2019). Hsu et al. (2017) proposed a theoretical framework based on the TPB model to investigate the relationship between the variables and explain consumers' purchase intention of green skincare products. The intention to transact or purchase intention is defined as buyers' intention to engage in the exchange relationship at shopping websites, such as sharing information, maintaining business relationships, and creating business transactions (Zwass, 1998). Ling et al. (2010) analyze how shopping orientations, online trust, and prior online purchase experience influence customers' online purchase intention. Kelley (1958) defined convenience cost as the expenditure of time, physical and nervous energy, and money required to overcome the frictions of space and time, and to obtain possession of goods and services and described four forms of place convenience, one of the ten types of convenience. Brown et al. (1992) defined convenience as a reduction in the amount or consumer time and/or energy required to acquire, use, and dispose or a product or service relative to the time and energy required by other offerings in the product/service class, and suggests a two-dimensional construct organized in the acquisition, use, and disposal phases ( $\mathrm{Li}, 2015)$. When many firms compete for the same consumer with homogeneous product offerings, price defines the competitive position and is a powerful competitive 
weapon (Dolan \& Simon, 1996; Kotler, 2003). Comparison of the prices between the beauty products sold in drugstore chains to other shops will be evaluated to see if it affects the purchase intention.

\section{Hypothesis Development}

Lee et al. (2014) stated that shopping enjoyment for consumers is a prerequisite to acquiring good reviews or high ratings. To give consumers good reviews and high ratings, they must first enjoy shopping in the relevant social commerce sites. The authors divide shopping enjoyment into consumer empowerment orientation and interactivity, user-generated contents, and attractiveness. The findings show that shopping enjoyment is positively associated with purchase intention. Shopping enjoyment is created from the fun and playfulness of the online shopping experience rather than from the completion of shopping activities. Purchasing the product may be incidental to the experience of online shopping. Thus, shopping enjoyment reflects customers' perceptions of online shopping entertainment (Kwek et al. 2010). Seock and Bailey (2008) argue a positive relationship between shopping enjoyment orientation and customer online purchase intention. We can derive the following hypothesis:

\section{H1: Shopping enjoyment affects purchase intention.}

Convenience is a more complex opinion than simply providing quick checkouts or locations close to home (Kwek et al. 2010). Self-service technology creates a convenient way of shopping which consumers expect in retail transaction (Aguzman et al., 2020). Recent studies showed that convenience has a direct effect on purchasing trends (Mpinganjira et al., 2015). In the retail context, Moeller et al. (2009) investigated four dimensions of shopping convenience, decision, access, search, transaction, and after-sales convenience, and their impact on customer retention and loyalty. The results of Pham et al.'s (2018) study showed that all five dimensions of online shopping convenience have a positive effect on repurchase intention. It can be concluded that:

\section{H2: Convenience affects purchase intention.}

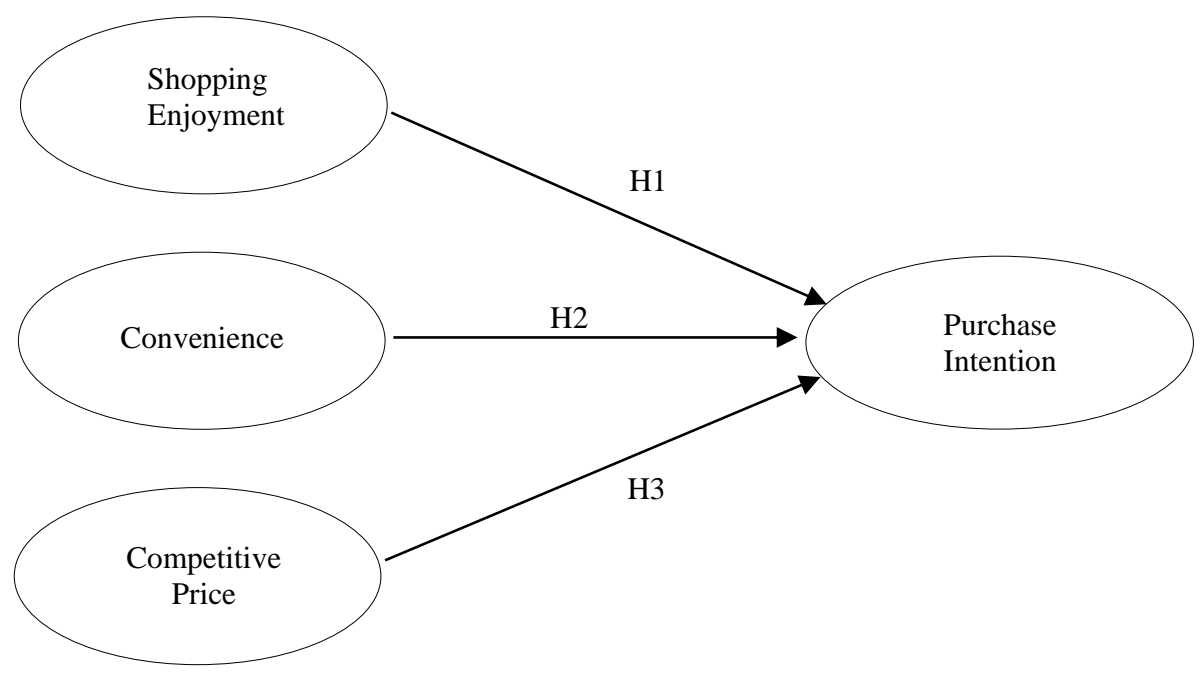

Figure 1. Research Framework

Competitive prices are consumer perceptions of the prices of products offered, whether prices are high, cheap, or standard, adjusted for product quality (Niraj \& Sanjeev, 2017; Cyr et al., 2006). Price is one of the benchmarks for consumers to decide on purchases which are then compared to the benefits obtained 
(Collier \& Bienstock, 2006; Petre et al., 2006; Niraj \& Sanjeev, 2017). Products with prices that match the benefits provided can make consumers decide on purchases (Madlberger, 2006). It can be concluded that:

\section{H3: Competitive price affects purchase intention.}

\section{METHODOLOGY}

The method used in this research is quantitative, in which hypotheses are being tested using statistics. A survey started in November 2020 which was administered by utilizing an online questionnaire platform comprised of questions in Likert scale measurement. From 132 distributed questionnaires using Google Form link, only 106 responses are valid, resulting in $80.3 \%$. The main part of the survey was built based on Likert scale measurement with the range of response options from " $1=$ strongly disagree" to " $5=$ strongly agree." The original items were in English and were translated into Bahasa Indonesia. The proposed framework model can be seen in Table 1 .

\section{RESULTS AND DISCUSSION}

A pretest was conducted on Smart-PLS based on 30 respondents' data to examine the validity and reliability of the questions. For the anti-image correlations, the values of AVE should be above 0.5. In conducting the reliability test, the result of the Cronbach's Alpha value will be a number between 0 and 1 and the test can be accepted if the values are 0.7 or higher. The summary of the validity and reliability of each questionnaire questions can be seen in Table 1 .

Table 1. Reliability and Validity of the Items

\begin{tabular}{cccccc}
\hline Constructs & Items & Loadings & Alpha & CR & AVE \\
\hline Intention & INT1 & 0.860 & 0.919 & 0.943 & 0.805 \\
& INT2 & 0.888 & & & \\
& INT3 & 0.936 & & & \\
\hline INT4 & 0.903 & & & 0.596 \\
Convenience & CONV1 & 0.808 & 0.888 & 0.912 & \\
& CONV2 & 0.816 & & & \\
& CONV3 & 0.733 & & & \\
& CONV4 & 0.755 & & & \\
& CONV5 & 0.757 & & & \\
& CONV6 & 0.782 & & & \\
& CONV7 & 0.749 & & & \\
\hline \multirow{2}{*}{ Price } & PRICE1 & 0.768 & 0.827 & 0.896 & \\
& PRICE2 & 0.908 & & & \\
\hline Enjoyment & ERICE3 & 0.904 & & & \\
& ENJOY1 & 0.793 & 0.744 & 0.850 & \\
& ENJOY2 & 0.918 & & & \\
& ENJOY3 & 0.704 & & & \\
\hline
\end{tabular}

For demographic profile (see Table 2), it is known that the respondents mostly are women with $88.7 \%$ of the total respondents, while the other $10.4 \%$ are males, and $0.9 \%$ refused to answer, $82.1 \%$ of the respondents are between $18-21$ years old, $14.2 \%$ are between $14-17$ years old, and the rest $3.8 \%$ are between 22-25 years old. The respondents were expected to answer how important are beauty products for them on a scale of $1-10$, and the most number of respondents (32.1\%) answered 9 , while only $0.9 \%$ answered 5 , $23.6 \%$ of the respondents pick 10 as the highest score, and $1.9 \%$ pick 3 as the lowest score on the scale. 
Moreover, it is known that $49.1 \%$ of the respondents spend IDR 200,000 - IDR 500,000 a month on beauty products, 39.6\% spend less than IDR 200,000, 8.5\% spend IDR 500,001 - IDR 1,000,000, and the rest $2.8 \%$ spend more than IDR 1,000,000.

Table 2. Demographic Profile

\begin{tabular}{|c|c|c|}
\hline Factor & Characteristics & $\%$ \\
\hline \multirow{3}{*}{ Gender } & Male & 88.70 \\
\hline & Female & 10.40 \\
\hline & Refused to Answer & 0.90 \\
\hline \multirow{5}{*}{ Age } & $14-17$ & 14.20 \\
\hline & $18-21$ & 82.10 \\
\hline & $22-25$ & 3.80 \\
\hline & $26-30$ & - \\
\hline & $>30$ & - \\
\hline \multirow{10}{*}{$\begin{array}{c}\text { Importance of } \\
\text { Beauty Products }\end{array}$} & 1 & - \\
\hline & 2 & - \\
\hline & 3 & 1.90 \\
\hline & 4 & 2.80 \\
\hline & 5 & 0.90 \\
\hline & 6 & 2.80 \\
\hline & 7 & 10.40 \\
\hline & 8 & 25.50 \\
\hline & 9 & 32.10 \\
\hline & 10 & 23.60 \\
\hline \multirow{4}{*}{$\begin{array}{c}\text { Monthly Expense } \\
\text { on Beauty } \\
\text { Products }\end{array}$} & $>$ IDR 200,000 & 39.60 \\
\hline & IDR $200,000-500,000$ & 49.10 \\
\hline & IDR 500,001-1,000,000 & 8.50 \\
\hline & > IDR $1,000,000$ & 2.80 \\
\hline
\end{tabular}

The result of $\mathrm{R}^{2}$ is 0.615 which shows that that $61.5 \%$ of INT can be described through SE, CONV, and PRICE. The significance threshold for this study is set at $p \leq 0.05$, and the multiple $R(R)$ from the regression test describes the strength of the linear relationship between the variables. Since the result of the coefficient of determination is close to 0.5 , we can conclude that the linear relationship is strong.

Table 3. R-Square for INT (Intention)

\begin{tabular}{ccc}
\hline Construct & R-SQ & R-SQ ADJ \\
\hline INT & 0.615 & 0.604 \\
\hline
\end{tabular}

As Table 4 indicates, the $\rho$-value of shopping enjoyment of $0.000<\alpha(0.05)$, indicating it is significant and affects the intention factor significantly. It is found that convenience does not affect purchase intention of beauty products sold in drugstore chains $(\beta=0.223, \mathrm{t}=0.774)$. Therefore, hypothesis 2 is not supported. Since the $\rho$-value of competitive price of 0.000 is lower than $\alpha(0.05)$, it indicates that it is significant and affects the intention factor significantly. 
Table 4. Path Estimates

\begin{tabular}{lccc}
\hline & Path Estimates & $\boldsymbol{t}$ Statistics & P Values \\
\hline ENJOY -> INT & 0.304 & 3.722 & 0.000 \\
CONV -> INT & 0.083 & 1.070 & 0.285 \\
PRICE -> INT & 0.545 & 6.426 & 0.000 \\
\hline
\end{tabular}

\section{CONCLUSION}

Shopping enjoyment, convenience, and competitive price are essential factors for purchasing beauty products sold in drugstore chains. However, from the first validity test performed, one item was not valid, so the item was taken out of the test. The second test was performed to acquire all valid results. Later, the path coefficients show that $\mathrm{H} 2$ (convenience) is not significant.

The customers could not care less about convenience when it comes to shopping beauty products in these drugstore chains, which the long lines can also prove at the stores, crowded spaces, but all of these do not affect the number of visitors. Therefore, drugstore chains should improve on areas other than convenience like excellent service from the beauty assistants and store music to enhance their customers' mood.

\section{REFERENCES}

Aguzman, G., Pangaribuan, C. H., \& Sasongko, A. H. (2020). Self-Service Checkouts: The Role Of Service Innovation In Indonesian Convenience Stores. Psychology and Education Journal, 57(9), 8187.

Ajzen, I. (1991). The Theory of Planned Behavior. Organizational Behavior and Human Decision Processes, 50(2), 179-211.

Brown, L. G. \& McEnally, M. R. (1992). Convenience: Definition, structure and application. The Journal of Marketing Management, 2(2), 47-56.

Collier, J. E., \& Bienstock, C. C. (2006). Measuring Service Quality in E-Retailing. Journal of Service Research, 8(3), 260-275. doi:10.1177/1094670505278867

Cyr, D., Head, M., \& Ivanov, A. (2006). Design aesthetics leading to m-loyalty in mobile commerce. Information \& Management, 43(8), 950-963. doi:10.1016/j.im.2006.08.009

Dolan, R. J. \& Simon, H. (1996). Power Pricing: How Managing Price Transforms the Bottom Line. The Free Press.

Hsu, C.-L., Chang, C.-Y. \& Yansritakul, C. (2017). Exploring purchase intention of green skincare products using the theory of planned behavior: Testing the moderating effects of country of origin and price sensitivity. Journal of Retailing and Consumer Services, 34, 145152. doi:10.1016/j.jretconser.2016.10.006

Chaudhri, S. K. \& Jain, N. K. (2009). History of cosmetics. Asian Journal of Pharmaceutics, 3(3), 164. https://doi.org/10.22377/ajp.v3i3.260

Kelley, E. J. (1958). The Importance of Convenience in Consumer Purchasing. Journal of Marketing, 23(1), 32-38. doi:10.1177/002224295802300105

Kotler, P. (2003). Marketing Management. Prentice-Hall.

Lee, H. S. S., Khong, K. W. K., \& Hong, J. L. (2014). Influence of Online Shopping Enjoyment and Trust Towards Purchase Intention in Social Commerce Sites. Australian Journal of Basic and Applied Sciences, 8(8) Special, 62-67.

Ling, K. C., Chai, L. T., \& Piew, T. H. (2010). The Effects of Shopping Orientations, Online Trust and Prior Online Purchase Experience toward Customers' Online Purchase Intention. International Business Research, 3(3), 63-76. https://doi.org/10.5539/ibr.v3n3p63 
Madlberger, M. (2006). Exogenous and Endogenous Antecedents of Online Shopping in a Multichannel Environment. Journal of Electronic Commerce in Organizations, 4(4), 29-51. http://dx.doi.org/10.4018/978-1-59904-978-6.ch013

Mahran, H., \& El-Kilany, E. (2017). What Lies under the Chair! A Study in Ancient Egyptian Private Tomb Scenes, Part II: Objects. Journal of the American Research Center in Egypt, 52, 11-26.

Meixian, L. (2015). Convenience and Online Consumer Shopping Behavior: A Business Anthropological Case Study Based on the Contingent Valuation Method. The Anthropologist, 21(1-2), 817. doi:10.1080/09720073.2015.11891788

Moeller, S., Fassnacht, M., \& Ettinger, A. (2009). Retaining Customers with Shopping Convenience. Journal of Relationship Marketing, 8, 313-329.

Mpinganjira, M. (2015). Online Store Service Convenience, Customer Satisfaction and Behavioural Intentions: A Focus on Utilitarian Oriented Shoppers. Journal of Economics and Behavioral Studies, 7, 36-49.

Passafaro, P., Livi, S., \& Kosic, A. (2019). Local Norms and the Theory of Planned Behavior: Understanding the Effects of Spatial Proximity on Recycling Intentions and Self-Reported Behavior. Frontiers in Psychology, 10. doi:10.3389/fpsyg.2019.00744

Petre, M., Minocha, S., \& Roberts, D. (2006). Usability beyond the website: An empirically-grounded ecommerce evaluation instrument for the total customer experience. Behaviour \& Information Technology, 25(2), 189-203. doi:10.1080/01449290500331198

Pham, Q. T., Tran, X. P., Misra, S., Maskeliunas, R., \& Damasevicius, R. (2018). Relationship between Convenience, Perceived Value, and Repurchase Intention in Online Shopping in Vietnam. Sustainability, 10, 1-14.

Seock, Y.-K., \& Bailey, L. R. (2008). The influence of college students' shopping orientations and gender differences on online information searches and purchase behaviours. International Journal of Consumer Studies, 32(2), 113-121. doi:10.1111/j.1470-6431.2007.00647.x

Surber, C., \& Kottner, J. (2017). Skin care products: What do they promise, what do they deliver. Journal of Tissue Viability, 26(1), 29-36. doi:10.1016/j.jtv.2016.03.006

Zwass, V. (1998). Structure and Macro-Level Impacts of Electronic Commerce: From Technological Infrastructure to Electronic Marketplaces. McGraw-Hill. 